\title{
TOWARDS A POETICS, RHETORICS AND PROXEMICS OF VERBAL CHARMS
}

\section{Jonathan Roper}

This article is intended as a first attempt to assemble and, where necessary, to newly devise, a series of terms which can be used to indicate the poetical features ${ }^{1}$ and rhetorical structures and devices typically present in the words of a charm, and also the proxemic manoeuvres employed in the "performance" of charms. ${ }^{2}$ In the English-speaking world academic investigations into individual verbal charms and into whole charm traditions have tended to be undeveloped in approach and few in number, excepting, of course, the standard authorities on the Anglo-Saxon charms. ${ }^{3}$ Such studies of English-language charms as have been carried out, most especially in the late- and post-medieval fields, have been limited, hampered by the lack of adequate critical terminology. This tendency for charmstudies to be undeveloped when compared with studies of other aspects of folklore is not just apparent in the English-speaking world: Rørbye (1992: 435) discussing "the first wave of folkloristic documentation 1880-1960" in the Nordic countries, comments that folk medicine (the general area which the majority of charms fall under $)^{4}$ "was chiefly studied [--- as] a means to the end in the programme of evolutionistic reconstruction" i.e. it was admitted into folkloristics as a theme and not as a free-standing phenomenon or genre. Similarly, Conrad (1989: 422) remarks:

As if embarrassed by continuing popular faith in the efficacy of charms and incantations despite the availability of modern regional hospitals, Soviet folklorists until recently relegated newly collected examples to archives. Even the notable exceptions, major studies by Astaxova, Minkov, Petrov, Tokarev and Toporov, were published in books or journals with very small print runs.

Thus while primarily written from and addressed to the English cultural tradition, the article may also prove of interest to students of charms in other cultural traditions. The gathering-together of these terms, and the concepts they embody, from a variety of chiefly European sources, should help open up debate of local and com- 
parative charm-studies so that can go beyond the limitations common to the great nineteenth-century editions (or indeed to the less great twentieth-century volumes) of collectanea. To this end the key-words are marked out in bold type.

First off, a brief consideration of a few etymologies can help to better distinguish the subject of this study. Middle and Modern English $\mathrm{charm}^{5}$, (which is a French loan into Middle English ultimately derived from a reflex of the Latin word carmen 'song'), and Old English galdor, gealdor (which Grattan and Singer define as 'a common word always associated with singing for a magical purpose' ${ }^{\mathbf{6}}$ ), both imply a series of sung, or at the least, half-chanted, vocables. But on the other hand, the occurrence of tell, as root-word of the Middle English terms for a 'charmer', telster, and for a 'charm', teling, also, teoling and tellunge $)^{7}$, when considered together with the roots of other words of the same meaning in various other European languages (South Slavic odgovor, East Slavic zagovor, both from the common Slavic root govor, 'speech'; German besprechen and [Zauber]spruch, cognate with the German verb 'to speak'; Czech zarikat, again from the verb 'to speak') would suggest rather a sequence of vocables that is spoken. Then again, the Estonian term for verbal charm sõnad (or nõiasõnad), which simply means 'words' (or 'witch-words'), does not come down on one side or the other of the divide between speech and song, but is a definition which (seemingly at least) denies the power of the non- and subsensical. The phenomena which this article offers terms to describe occupies the common ground which all these definitions taken together imply: the force of patterned traditional utterance, a force which, when performed in a certain arena, and sometimes accompanied by gesture and medicine, has been credited with the power to bring about changes in health, fortune, safety and emotional state. So, verbal charms, or what are now commonly known as "spells", could be defined as traditional verbal forms intended by their effect on supernature to bring about change in the world in which we live.

\section{TOWARDS A POETICS OF VERBAL CHARMS}

The inclusion of verbal charms in collections of folk-verse e.g. Northall (1892), Grigson (1971), Holloway (1987), is a recognition of their poem-like qualities. ${ }^{8}$ It is indeed perhaps an over-elevation of 
the poeticalness of charms, at the expense of their practical intent and their more-than-textual, extra-poetical reality, by which they come to be considered as just another minor genre of vernacular literature. Putting such misgivings aside, however, we can note the aptness of certain critical terms used in the analysis of poetry for the analysis of verbal charms, those obvious terms such as "simile," "metre," "allusion," etc. which may well feature in critical descriptions of verbal charms, but need no definition here. Nevertheless, starting from Foley's (1980) incomplete but surely correct assertion that: "all charms depend for their magic on oral performance and sound-patterns," our critical vocabulary will need to include terms for the various types of sound patterns (i.e. perceptible repetition of phonemes). ${ }^{10}$ These include alliteration, assonance, metathetical repetition, for example, alcu cluel sedes adclocles in an Anglo-Saxon charm against "the Black Blains" (Storms 1948: 301), ablaut reduplicatives (ziguri zäguri is a Seto example of this), repetition of words, morphemic repetition (that is, repetition of part of a word), both occasional and regular end rhyme, internal rhyme and nearrhyme. In a handy phrase from the same article, Foley refers to the "incantatory force" of a (successful) charm, which we can put down in part to such sound patterning. Foley's assertion above, is incomplete, however, because the thought-world of the charmer and the charmed must also be vital in the process; this is acknowledged both by those who ascribe any benefits accruing from the use of verbal charms in healing to psychosomatic processes, and, often in our own time, by folk-healers themselves. ${ }^{11}$ Sound-patterning must be a compositional aid, and must surely also function as a mnemonic device organizing the charmer's recall. But Lord (1995: Ch. 1) strikingly argues that end-rhyme, in texts of an oral-formulaic character, hampers memorization.

Because English is a language relatively rich in phonemes, however (when compared to Italian, for example, or Finnish), it can be very difficult to achieve sound patterning with pertinent, or even semi-pertinent ${ }^{12}$, words and phrases. One might note, for example, how much more frequently contemporary English poets shy away from using rhyme when writing in modes of high seriousness, when compared to their Russian or Spanish counterparts. So, syllables with a high degree of semantic redundancy, which are frequently found in the charm traditions of this and other cultures, may still 
be significant ${ }^{13}$ : not semantically, but as significant sound. ${ }^{14}$ This notion allows us to see how echoic series of phrases, nonsense syllables and near-nonsense syllables, abracadabra words, ${ }^{15}$ foreign words, macaronicisms, ${ }^{\mathbf{1 6}}$ nonce words, unclear archaisms, tautological expressions, magic names (voces magicæ, or, in the singular vox magica), holy names ${ }^{17}$ (nomines sacrorum, or, in the singular nomen sacrum), synonyms, epithets, attributes, euphemisms and other forms of extended naming can, by realizing significant sound patterns, be significant. In the Anglo-Saxon charm Wið færstice we find mention made in line 16 of syx smiðas [---] sætan. Storms (1948) remarks that smiths did not occur in sixes in any known Germanic mythology i.e. in the absence of any other evidence, we are led to assume that "syx" is there simply to form this alliterative sound pattern. Even when we have total nonsense, "gibberish charms" such as this one against demonic possession from fifteenth-century Bavaria: Amara Tonta Tyra post hos firabis ficaliri Elypolis starras poly polyque lique linarras buccabor uel barton vel Titram celi massis Metumbor o priczoni Jordan Ciriacus Valentius (Kieckhefer 1990: 4 ), or total nonsense metrically arranged and with traces of phrasal or whole-line structure, "jingle charms":

1 Ecce dolgula medit dudum
2 beðegunda breðegunda
3 elecunda elevachia,
4 mottem mee renum [---]

there may still very well be some incantatory force to it.

Conversely, there can be such a phenomenon as significant omission, the non-production of the expected. To give an example, we can take lines 7-9 of the Anglo-Saxon charm for theft of cattle, beginning Ne forstolen ne forholen nanuht:

7 find bæt feoh and fere pæt feoh

8 and hafa bæt feoh and heald bæt feoh

9 and fere ham prtfeoh.

Vaughan-Sterling (1983: 199) notes that the omission of the last bhalfline "may even be another way of enforcing the meaning and emphasis of the first half-line," i.e. it underscores the culmination of the five-member $b æ t$ feoh series. Metrical anomalies of this and 
other kinds are common in the Old English "Metrical Charms". Not one of the twelve so-called "metrical charms" that we have records of from this period exhibits the metrically-required structural alliteration throughout. In Estonian, a loan word (from Finnish) loits is used as a label for charms in verse-form. ${ }^{19}$ In this article, we too shall be borrowing this word (as both a single and a plural noun) as a replacement for the currently-used term "metrical charms", which is inappropriate because charms frequently exhibit both submetricality and hypermetricality not just in Anglo-Saxon times, but throughout the English cultural tradition. ${ }^{20}$ This is presumably because in the event of any conflict whether between producing significant sound or sensible, purely referential meaning, or between producing significant sound or adhering to a regular metre, the tradition will regularly opt for producing significant sound, and to use the neutral term loits does not suggest anything other than that.

A verbal charm is performed verbally, regardless of whether it is held in the memory or on paper, while a written charm does its work without being spoken: the text used as an amulet (n.b. magically-endowed artefacts, such as jewellery, carried by or hanging from a person are vernacularly known today as "charms", which may be a reflection of a past practice that involved words being pronounced over such objects in order to enchant them). Despite this distinction, written charms are, more often than not, written versions of originally verbal charms; both written and verbal charms exhibit the primary feature of oral literature, the presence of formulæ (Lord 1960). A formula is a verbal paradigm, usually with substitutable and expandable elements, that tends to recur in a particular text, and also in other texts. ${ }^{21}$ Though some are unchanging fixed formulæ, many are flexible formulæ which can be inflected, split up, ${ }^{22}$ transposed, expanded, etc. The chief means of expanding flexible formulæ tend to involve adding adjectives (by the multiplication of epithets), and adding nouns (by providing formulaic merisms with extra members and thereby transforming them into lists). Expansion by the addition of verbs is less common. As well as noting that the flexibility of formulæ may change over time (with expressions loosening up or ossifying), one should make the concomitant observation that some formulæ are more flexible than others, for example, formulaic kennings (such as, to give a Seto example, mõtsa nõgil 'forest needle' i.e. snake) are not by their nature 
expandable. Formulæ themselves can be free-standing miniatures of sound-patterning, sometimes even miniature ${ }^{23}$ of sonic ring composition, ${ }^{24}$ that is beginning and ending with the same sound(s), such as /ei/ in "Rain, rain, go away". Such self-contained formulæ may well be older (or to put it another way, less original) than the rest of a charm.

Traditional formulæ are those characteristic not of a single composer, but of a tradition, more particularly, an oral tradition, although so-called transitional texts, such as Calvino's retellings of Italian folktales or the Pesistratian recension of the Homeric poems, may also have a residue of formulæ. Single composers may have their own idiolectal formulæ, or even nonce formulæ, ${ }^{25}$ phrases coined on the basis of similar formations, but intended for a one-off purpose. Local formulæ and indeed dialectal formulæ also exist. To give an example, the formulaic alliterative doublet halu ja haigus 'pain and disease' is only evident in South Estonian dialect charms, as in Standard Estonian 'valu' replaces the local term 'halu'. Formulaic constituents (the words or groups of words which together constitute a formula) often tend to be fixed in order of appearance (for example, we always say goods and chattels, never *chattels and goods). ${ }^{26}$ "Chattels" can be described as being a formulaic word in Modern English, in that it occurs almost always in the context of this formula.

The Shipping Forecast is an example of a formulaic series, a succession of parallel phrases whose substitutable elements - shipping area, wind speed, visibility - variously change or are repeated in the framework of unchanging syntactic paradigms during the "performance" of the forecast. In fact, because the shipping forecast uses the same formula throughout with its respective variations, it is a monoformulaic text, and part of its restful effect on inlanders must be that, in contrast to the normal practice in charms, its formulaic series is a catalogue, a parallel series, and not an incremental series.

Formulaic series can be referred to by their recurring elements, as for example in the Anglo-Saxon charm AEcerbot, where the lines 5457 exhibit the wæstum series: 
54 sceafta hehra, scirra wæstma,

55 and pæra bradan berewæstma

56 and pærahwitan hwætewæstma,

57 and ealra eorbon wæstma.

Another hallmark of formulæ is that they are (pragmatically) restricted in their deployment, only being used in certain contexts, genres, or even, as in the example above, in a common metrical slot, always realizing the fourth beat by being at line-end. In Parry's initial oral-formulaic theory, based on the "ideal" cases of South Slav epic verse and Homeric epic, ${ }^{27}$ the concept of metrical slot played a much more essential role than is now assigned to it by researchers who have discovered evidence of formulæ in all sorts of literature and orature, including non-metrical kinds.

Formulæ can also be referred to by their function. Bartashevich (1993), in his list of the types of formulæ typical of East Slavic charms, includes introductory formulæ - most commonly in Russian examples Vstanu ia, paidu v chistoe pole 'I arise, I go to the clean field'28 - , enumerating formulæ, formulæ of unfulfillable conditions, formulæ of the impossible, expulsory formulæ, threat formulæ, cursing formulæ and desire formulæ. This use of formulæ means that some charms can be considered, like the Latvian dainas, or, also, women's songs in the language we used to call Serbo-Croatian, as lacking in anything which can rightly be called an original version, as being multiforms. A multiform consists of the sum of all its variants, likewise a multitext is a representation of this; it is what emerges when all the different recorded versions of the same person performing the "same" text" $\mathrm{t}^{29}$ are put down together on paper. Multiforms with few and minor variants are straightforward to represent (and to read) in the form of a multitext similar to a variorum edition of a poem, but more complex examples with a higher degree of multiformity may require representation in the form of a building-block level set of basic frames or parts, and a variant table showing which variants use which of these possible parts from the repertoire, and in which order.

To devise such a table first requires an editorial decision as to which variant is most suited, by it completeness and representativeness, to be the base from which all others are to be described. So, out of the seven variants of a charm listed below: 
W. Crossing:

Three Angels came from North, East and West, One brought fire, another brought frost, And the third brought the Holy Ghost

So out fire and in frost

In the name of the Father, Son and Holy Ghost.

(Recorded in Devon, cited in Crossing 1911)

S. Pepys:

There came Three Angels out of the East;

The one brought fire, the other brought frost-

Out fire; in frost,

In the name of Father, and Son, and Holy Ghost. Amen.

(Recorded in London by Samuel Pepys in 1664, cited in Newall 1974)

K. Thomas:

Two angels came from the West.

The one brought fire, the other brought frost.

Out fire! In frost!

In the name of the Father, Son and Holy Ghost.

(Recorded near Tavistock in Devon, cited in Thomas, 1971: 212)

C. Latham:

There came two Angels from the North;

One was Fire, one was Frost.

Out, Fire; in Frost,

In the name of Father, Son and Holy Ghost.

(Recorded in Sussex, cited in Latham 1878: 35)

R. Whitlock 1:

Three wise men came out of the east,

One brought fire and two brought frost.

Out fire! In frost!

In the name of the Father, Son and Holy Ghost.

(Recorded in Devon, cited in Whitlock 1977: 167) 
R. Whitlock 2:

Three ladies came from the east, One brought fire, two brought frost, Out with fire, and in with frost, In the name of the Father and of the Son and of the Holy Ghost. Amen. Amen. Amen.

(Recorded in Wiltshire, cited in Whitlock 1992: 105)

P. E. B. Porter:

There were two giants came from the East, One wrought fire and the other wrought frost;

Out fire and in frost;

In the name of Father, Son and Holy Ghost.

(Recorded in Devon, cited in Porter 1905: 108)

R. E. St. Leger-Gordon:

Three Angels came out the South

One was fire, one was frost and one was the Holy Ghost, Out fire, in frost.

In the name of the Father, Son and Holy Ghost.

(Recorded in Devon, cited in St. Leger-Gordon 1982: 174)

we might choose the longest variant that cited by W. Crossing as the base. We must now subdivide it in to word-groups, lines and line-groups of a size matching the units which are varied or replaced in the other variants, thus:

a Three Angels

$b$ came from

$c \quad$ North, East and West,

$d$ One brought fire,

$e \quad$ another brought frost,

$f$ And the third brought the Holy Ghost

$g \quad$ So out fire

$h$ and in frost

$i \quad$ In the name of the Father, Son and Holy Ghost.

Now a list of the variants for each of these units that we are interested in can be drawn up. So if we choose to ignore differences in 
punctuation and orthography (these are after all non-regularized transcriptions of oral forms), as well as the slight differences in the In nomine in unit $i$, we have the following:

$a_{1}$ Three wise men

$a_{2}$ Three ladies

$a_{3}$ Two angels

$a_{4}$ Two giants

$b_{1}$ came out of the

$b_{2}$ there came

$b_{3}$ came from the

$b_{4}$ from the

$b_{5}$ out of the

$b_{6}$ there were

$b_{7}$ came out the

$c_{1}$ east

$c_{2}$ south

$c_{3}$ west

$c_{4}$ north

$d_{1}$ the

$d_{2}$ one was fire

$d_{3}$ one wrought fire

$e_{1}$ and

$e_{2}$ two brought frost

$e_{3}$ one was frost

$e_{4}$ the other brought frost

$e_{5}$ the other wrought frost

$f_{1}$ and one was the holy ghost

$g_{1}$ out fire

$g_{2}$ out with fire

$h_{1}$ in frost

$h_{2}$ in with frost

$h_{3}$ and

$j_{1}$ Amen 
The seven other examples are now representable in this variant table:

$\begin{array}{ll}\text { Pepys: } b_{2} a b_{5} c_{1} / d_{1} d e_{4} / g_{1} h_{1} / i j_{1} & / / \\ \text { Tavistock: } a_{3} b_{3} c_{3} / d_{1} d e_{4} / g_{1} h_{1} / i & / / \\ \text { Latham: } b_{2} a_{3} b_{4} c_{4} / d_{2} e_{3} / g_{1} h_{1} / i & / / \\ \text { Porter: } b_{6} a_{4} b_{3} c_{1} / d_{3} e_{1} e_{5} / g_{1} h_{1} / i & / / \\ \text { St. Leger-Gordon: } a b_{7} c_{2} / d_{2} e_{3} e_{1} f_{1} / g_{1} h_{1} / i & / / \\ \text { Whitlock 1: } a_{1} b_{1} c_{1} / d e_{1} e_{2} / g_{1} h_{1} / i & / / \\ \text { Whitlock } 2: a_{2} b_{3} c_{1} / d e_{2} / g_{2} h_{3} h_{2} / i j_{1} j_{1} j_{1} & / /\end{array}$

The list of variant units and the variant table itself are easily extensible when new versions need to be described.

R. E. St. Leger-Gordon, commenting on a variant of a charm displayed above, complains that "the words are obviously the products of primitive uneducated minds, a jumble of illiterate doggerel [---] ungrammatical, unpunctuated and mis-spelt" (St. Leger-Gordon 1965: 174). Without counter-claiming that verbal charms are great literature (although similar use of formulæ and varied repetition does appear in Homer, the Bible, Beowulf and so on), one can believe that this onslaught misses the point. One feels that here "illiterate" is not being used as an objective descriptive term to refer to those whose verbal culture is predominantly oral, but is simply one more example of the condescension Walter J. Ong has shown to often exist (most forcefully in Orality and Literacy, 1982) when modern, educated minds encounter the very different products and processes of oral cultures. To keep St. Leger-Gordon on here as our whipping boy, we can see that calling highly-structured form "a jumble" is evidently a failure to perceive that order, and to remark that "any old abracadabra would answer the purpose equally well" (St. Leger-Gordon, loc. cit.) is a failure of empathy. Were we to start a civilisation anew, completely from scratch, then we could perhaps choose any sequence of formulaic words with which to solemnize marriages, or to affirm one's truthfulness in court, but given that we are born into pre-existing cultures with traditions and norms that pre-date our period of personal existence, these required verbal forms and the tones of voice for their delivery also have been pre-appointed as what we are born to. Our enculturation makes us 
as, say, wedding-guests, as suspicious of departures from the required idiom and formulæ at a marriage ceremony, as departures from what is judged as in-keeping in the required magical idiom would sound to traditional audiences of verbal charms. In both cases, the whole legitimacy of the important performative speech-act would then be in question.

John Miles Foley, in his essay Reading the Oral Traditional Text, refers to what he calls the "multiform idiom" (Foley 1987: 192-194), which is that particular use of words - repetitive, generic, resonant - that characterizes multiforms. This non-original idiom is a tradition-abiding and appropriate "way of saying" in traditional cultures. So, as he remarks elsewhere, if a recurrent scene, or a recurrent phrase such as "“swift-footed Achilles" or "grey-eyed Athena" is in its own way as idiomatic as "once upon a time" or "Little Red Riding Hood", then to forego its deployment is also to forego its inimitable significative power" (Foley 1996: 24). The traditional audience will appreciate this, and not condemn such use of language for being clichéd and lacking in originality.

A deep text is the hypothetical pattern the utterer of a charm follows in "performance." Unlike surface texts, their so-called "realization" in words, deep texts are virtual, do not consist of words, and, as theorists following Propp (1958) have contended, are divisible into units, usually called motifemes. So, to give an example, Güttgemanns (1977) theorizes that differences between the wording and composition of stories common to all three Synoptic Gospels are only differences in allomotifs (that is, in "realizations" in words of the same motifeme). The differing stories of (and the variety in the connections between, embeddings, deletions and repetitions within) Matthew, Mark and Luke amount, he proposes, simply to paraphrastic expressions of the same deep text.

It would seem that the passing of such an oral text from a first charmer to a second charmer would be an example of tight transmission. ${ }^{30}$ Tight transmission can be opposed to loose transmission, which allows for deletion and innovation, and to forgetful transmission, in which sections can be partially or wholly lost (especially lists and series), or affected by cross-contamination by parts of other charms. ${ }^{31}$ Because transmission sometimes involves the first charmer losing the power to use it, this presumably making her or 
him anxious to ensure that it has been successfully handed down. Another argument in favour of the belief that tight transmission is involved here is that reciters seem to carefully reproduce a charm, even if it be unclear to them, ${ }^{32}$ although, of course, some variation may enter unconsciously by processes of auditory substitution, ${ }^{33}$ mishearing, or in the case of written charms, misreading, and miscopying. Thus, unlike the primarily improvisational oral tradition that Parry, and later, Lord found in the epic songs of the former Yugoslavia, charms in Europe are and were an example of a primarily memorial oral tradition, like the British ballad tradition, in which oral texts (though perhaps composed with formulæ initially by the first maker of a certain charm) are primarily memorized, and are performed more or less the same.

A term related to the concepts discussed above is text fixation, which describes a process by which a multiform oral text is "fixed" by being written down in a single variant which is from then on the text. Variations can only enter a fixed text by scribal error. If a text is not fixed, then it can be very difficult to judge whether a single performance of it with significant variations is a valid realization, or is simply mistaken. What are the criteria to go by - what the charmers themselves thinks, what other people and especially other charmers think, whether the charm works or not, etc? Moreover, false starts, arbitrary omissions and additions are only identifiable as such synchronically. Diachronically, of course, errors (or innovations) are incorporable, and innovative versions can become (local) standards. Such re/de-formations of charms and particular lines in charms can be fairly labelled as corruptions if they result in internal inconsistencies or other semantic problems, and we can thus use the less pejorative terms reduction to describe a charm which is basically similar to its predecessor, but omits elements of it, and expansion to describe the reverse phenomenon, a charm with superadded material.

Expansions, and often unexpanded charms too, for that matter, often make use of intensifying devices such as anticipation and recapitulation of some particular idea or phrase, as well as of repetition, particularly used to form groups of threes: triplication. Consider, for example, the Anglo-Saxon charm generally known as For Delayed Birth, where the verbal triplication 
bis me to bote pære lapan lætbyrde, pis me to bote pære swæran swærbyrde, pis me to bote pære laðan lambyrde.

is uttered by the woman in question as she steps over a dead man's grave three times.

The repetition with minor changes, as found in formulaic series such as catalogues, is known as varied repetition (commonly, anaphoristic repetition and cataphoristic repetition), while repetition of whole line-groups, reminiscent of refrains in songs, is known as structural repetition. The repetition in the Nine Herbs Charm, 11. 5-6,

bu miht wip attre and wið onflyge

bu miht wip bam lapan ðe geona lond færð

and 1l. 19-20,

beos mæg wip attre, heo mæg wið onflyge

heo mæg ðam lapan ðe geona lond fereb.

is, because of the slight changes it involves, varied structural repetition. Repetition can also be said to be hierarchical - in the lines quoted from Accerbot above the predominant repetition is of wæstma, while the secondary repetition, which appears in just the middle two of the four lines, is of and pæra. In fact, repetition, whether of sounds, words, or syntactic units is perhaps the key characteristic of verbal charms, as it is of rituals in general. ${ }^{34}$

The principle at work behind the surface features described in the last paragraph is that repeating an idea or a word strengthens it. This is evident in the so-called numeric charms, where, in a manner reminiscent of some nursery rhymes, the words of a charm are repeated, and each time a significant number (often initially nine) is reduced by one:

Tetter, tetter, thou hast nine brothers,

God bless the flesh and preserve the bone,

Perish thou tetter, and be thou gone,

In the name of the Father, Son and Holy Ghost. 
Tetter, tetter, thou hast eight brothers, [---]

(Text cited in Northall 1892: 129).

This process of "counting down" is continued until zero is reached, and by analogy the unwanted phenomenon (for example, a wart) is also supposed subsequently to diminish to nothing.

A similar belief in the magical value of numerals lies behind what can be termed numeric reinforcement, the addition of numerals to descriptions, as in line 16 of Wið færstice quoted above, where we have not just a smith, or smiths, but precisely six smiths. A related form of reinforcement is enumeration, or making lists by breaking down into parts what could otherwise be taken as a whole: for example, the charm can more elaborately speak of which parts of the body the disease is to leave, as it were a series of metonyms for the body as a whole, rather than simply commanding a disease to leave the body, full stop. Such enumeration can reveal the organizing number (or numbers) of a charm: if, for instance, an animal catalogue lists only four or eight animals in all its variant occurrences, this implies that the organizing number here is four. Magic numbers, by contrast, need not be organizationally or structurally important in a charm, but rather be of value simply by being alluded to. It may be deemed necessary for an entire charm to be be pronounced a set number of times to be effective: this is the threshold number.

The terms outlined above, and those yet to be discussed below, properly apply only to traditional or tradition-dependent charms, and to tradition-smoothed idiosyncratic charms. Post-traditional charms tend not to be describable in such terms: the large number of "spells" on the shelves in any New Age section of a bookshop have been devised after the end of a once-living tradition. So they may make mention of magic numbers, while lacking a traditional organizing number, or feature all sorts of other unmotivated and arbitrary elements. At all events, they are remarkable for being the work of a single author and thus possessing personal and authorial features not as yet worn down or smoothed away by the results of oral transmission and widespread diffusion. Such post-traditionality is characteristic of texts composed after the loss of a particular (usually oral) tradition of composition. These texts are often unsuccessful attempts to replicate the supposed effect of traditional charms via 
different though sometimes superficially similar means. It is not, however, impossible that these idiosyncratic charms may be pretraditional - if they become the basis of verbal charms used long years ahead.

\section{TOWARDS A RHETORIC OF VERBAL CHARMS}

A rhetoric of charms should be concerned with the typical structures, compositional devices and typologies of the genre, and, considering charms as another type of code-communication, with the particular means of encoding information that they deploy. Nonnarrative charms ${ }^{35}$ may just be simple spells which use formulæ parallelistically as a device of comparison, as for example in this Cheremis charm (Sebeok 1964: 359):

\section{Olma-pu kuze peled «n šinćčš, tug-ak tid «püč \&m «kušk«šičšs»!! \\ As the Apple-tree blossoms forth, just so let this wound heal!}

The metatype, that is the basic structure which lies behind the form of words used, but does not in fact exist itself, for charms such as these is: as A, so B. Typically, A is a natural, inevitable, beneficent process, and B is a process currently desired by the charmer and his patient. The charmer, by yoking together these concepts and drawing on traditional language and the power of context, works magic by analogy.

The typical sections of a narrative charm,${ }^{36}$ however, speaking of an ideal pan-European case, are more numerous: invocation, introduction, with perhaps a formulaic opening command, historiola (or epic passage), magic formulæ and ratification. The last three of these terms call for special comment. A "historiola" is literally a little story, in which the protagonists or protagonist (usually a saint, or a Biblical or Apocryphal character, sometimes represented with their particular attribute) overcomes an antagonist - whether that be a malevolent character, force or disease. The little story presents an analogy between the recent situation and a mythical precedent of it, in which, to use the jargon of the structural analysts of folktales, a lack is "liquidated". This resemblance, though, "need not be any 
closer to the action which enables a saint to be considered a patron of an occupation or profession. St. Christopher carried Christ over the river; hence he is an appropriate saint for taxi-drivers" (Bloomfield 1964: 538). Sometimes the historiola is so short that it is debatable whether the charm is a narrative one, or a non-narrative one with a bare narrative allusion sufficient enough to allow the presentation of an analogy, as in the allusion to the Biblical story of the Virgin Birth in the altogether rather short Charme, for [---] A Cramp that Pepys recorded in his diary on the last day of 1664:

Cramp be thou Faintless, As our Lady was sinless, when she bore Jesus.

Sometimes, a negative analogy is drawn, as this translated Russian example shows:

Just as here on earth no-one sees seventh heaven, So may this grain not be fruitful in its turn.

The type-scenes of Anglo-Saxon epic poetry, e.g. the beasts of battle scene, or the hero on the beach scene, are not pace Foley (1995: 112) similar to the "frames" in a charm, but they are rather reminiscent of historiolas in that they are both formulaic episodes, serving as a build-up to a climax. When a historiola or epic element in a charm is as short or allusive as the last two examples above then the charmer loses one of the subtler and craftier side-effects of using such stories. In Pepys' example the charmer has to directly address the cramp; how much more effective (and less dangerous) if a story can lead on in such a way that the magic formulæ are part of the protagonist's dialogue. In this nineteenth-century Lancashire example (in this case a written charm intended "to be worn inside the vest or stays and over the left breast") complete with dialect spellings of a common European charm against toothache:

Ass Sant Peter sat at the geats of Jerusalem, our Blessed Lord and Saviour Jesus Christ pased by and sead: What Eleth thee, he said Lord my Teeth ecketh. Hee sead arise and folow me and thy Teeth shall never Eake Eney moor. Fiat Fiat Fiat 
the referent of "thy" is ambiguous; it could as well refer to the patient as it could to St. Peter. In a version collected in mid-Sussex by Charlotte Latham in the 1860s (Latham 1878: 40), again as a written charm, in this case found on the fly-leaf of a Book of Common Prayer belonging to "a Sussex labourer", Joseph Hylands, the persona "Jesus" makes himself even clearer on the matter of whom he is curing:

As Peter sat weeping on a marvel stone, Christ came by and said unto him, "Peter, what hailest thou?" Peter answered and said unto him, "My Lord and my God, my tooth eaketh." Jesus said unto him, "Arise Peter, and be thou hole; and not the only but all them that carry these lines for my sake shall never have the tooth ake."

The trick of this is that it is "Jesus" who is healing the patient; or alternately we could say that the patient has become a character in the epic or mythic world. Either way, it has, to use the phrase of Lévi-Straus (1963), a great deal of "symbolic efficacy". ${ }^{37}$ Whether the charm-makers were conscious of it or not, it is evident that the settings for historiolas e.g. gates, roads, watersides and bridges, are places of passage. Magic helpers, who achieve the charmer's goals by their actions in the mythical world of the charm, are similarly effective symbols. For instance, in the Old English charm Garmund 'Against Theft' (whose name literally means 'spear-protector' is invoked as such a helper, and is requested to find and fetch back the stolen cattle. Magic helpers can also be thought of as the personifications of magic names.

After magical power has been built up and called up by the invocation, magic names, historiolas and the like, it is time to release it. The transition to this release is sometimes marked by a change of verbal tense, often by one of mood, and by the use of more closely repetitive and formulaic language: often a series of "you"-formulæ in the imperative mood, the classic type of magic formulæ. These are commands, although their impact may be softened by attempts at persuasion (in the case of healing charms, by telling the sickness or the agent of sickness that it can go to a much better place than remaining inside the patient) or harshened by threats. Widdowson (1977: 28) notes, in the context of a discussion of traditional verbal controls over children, that the "linguistic structures of charms, 
curses and threats is often similar", for instance, "some charms, like threats, may take the form of an adjuration." Indeed Widdowson's comments about the efficacy of a threatening Bogeyman figure to control children's behaviour - "if [---] the adult apparently connives with some external agency to frighten the child into obedience he may be convinced that the adult is serious when this is not in fact the case" - are reminiscent of the added effectiveness brought to charms by the mediating protagonist figure of a charm's historiola. It is notable that charms can survive in a sceptical world in the form of childlore, where, of course, they are not thought of as being proper charms at all. "Raine raine goe away, Come again a Saterday" (Northall 1892: 33) is in its way a magical formula: the rain is invoked by true-naming (rather than as often happens by being referred to by its pejorative attributes), then comes the expulsory element ("Go away"), and there is an attempt to emoliate this harsh command by an element of bargaining - persuading the rain that if it does go now, then a later return is fully permissible.

In healing charms however, the sickness or its agent are not simply expelled and then sent off anywhere ("Go away" is not very specific), they are banished somewhere concrete, sometimes to an unfortunate thing or being not far off, but more usually either to somewhere far-away in the real world, or to an irreal anti-world. An anti-world is a mythological territory where phenomena happen in a reverse way to that in this world. If the place(s) of exile is described (or if anti-phenomena are enumerated) then it is clearer whether the banishment is to somewhere distant or whether to somewhere mythical where cats do not miaow and sheep do not baa. Often, and perhaps deliberately, insufficient data is given to establish where the sickness is heading. Alternatively, diseases and disease-spirits may be set formulaic impossible conditions (in distinction to possible conditions such as "Come again a Saterday"), which if met would permit them to have their way. For example, a Cheremis charm for stomach upset says that if the bellyache (or the spirit of the bellyache) can, in an hour, achieve the impossibility of eating the heart and liver of "the great god's daughter", then it may devour the sufferer too. This, of course, is expulsion by any other name. 
Magic formulæ which do not involve the conjuration or adjuration ${ }^{38}$ of supernatural powers, but have, for example, the patient as their addressee, tend, however, to be less imperative, and more conditional, as can be seen if we take, for the moment anyway, religious blessings and exorcisms as being forms of linguistic magic. Whereas the exorcisms use imperatives, benedictions rely on the modals such as "may". One might further note that if canonical prayers (or other religious texts) are used in a magic context, where unusual, extrareligious conditions are to be fulfilled, they can, with more justification, be seen as forms of verbal magic. In such a context prayers nominally to God (or Jesus or the saints), may not in fact have such an addressee. This is perfectly explicable, as the rhetorical addressee of, for instance, a charm (a spirit, a disease and so on) may well not be the audience of that charm. From a rationalist point of view the audience, the illiterate or semi-literate listener(s), is usually the de facto addressee(s). The sower of corn who recites an agricultural charm can be said to be his own audience, his own indirect addressee and reassurer.

Another typically important feature of charms is how they conclude, if they do not end with the utterance of the magic formulæ. This kind of conclusion-section is particularly common in East-Slavic charms where it has a name of its own - zakrepka - conventionally translated (e.g. by Conrad 1989) as "ratification", although a more colloquial rendering might be "clincher". Like "Amen" after a prayer, ${ }^{39}$ this is intended to clinch everything that has preceded it. Closing formulæ are used in many genres of folklore: Sunkuli and Miruka (1990: 18) provide us with an example of a Bura (Nigeria) closing formula - "Off with the rat's tail" - which typically is used to conclude oral narratives in that culture. Closing formulæ are also typical of some non-folkloristic genres of verbal art, but "ratifications" in literature do not consist, either totally or even in part, of non-verbal actions, unlike, for example, the Lancashire charm against toothache discussed above, in which the ratification involves making the sign of the cross: Fiat Fiat Fiat.

Just as was shown above, that a line can simultaneously be a historiola and also play the function of an origins-section, so a magical formula can also serve simultaneously as a ratification. In both of two charms recently collected during fieldwork in the Seto region 
of Estonia (Mrs. Kalasaar's charm against sprains, and Mrs. Lillestik's charm against snakebite $)^{40}$ the final formula simultaneously works magic and ratifies that magic (and ratifies the other magic formulæ which have gone before it). The two respective ratifications are versions of the same flexible formula, and as the two charms were in fact passed down to Olga Kalasaar and Nati Lillestik by the same woman, their common aunt Meljana Müürsepp, we can conclude that Mrs. Müürsepp, though she knew two charms, only had one conclusive magical formula in her repertoire. Her words were luust lihast kadoma halu ja haigus 'from bone, from flesh, be lost pain and illness!' and su lihast ja luust välja kaotma 'out from your flesh and bone be lost!' Other formulæ with something in common can be found in the archives, such as N.N. luust ja N.N. lihast / kuijoma ja kaoma 'from N.N.'s bone, from N.N.'s flesh/ dry up and be lost!', ${ }^{41}$ Luust lihast vella ${ }^{42}$ and Luust lihast välja ${ }^{43}$ (both meaning 'out from bone and flesh!'). These other formulæ are not close enough to be considered as variants of a common flexible formula, but nevertheless have some mutual resemblance, and can be considered as members of the same formula family. ${ }^{44}$

To briefly illustrate several of the terms used above, we can look again at a charm mentioned above which Pepys recorded on the same date as the example above, 31st December 1664, this one for dealing with burns:

There came Three Angels out of the East;

The one brought fire, the other brought frost-

Out fire; in frost,

In the name of Father, and Son, and Holy Ghost. Amen.

The first two lines make up the historiola, the third the magic formula, and the fourth the ratification. This charm is interesting not just for its internal inconsistency (where is the third angel and what did he bring?), which suggests that it is a corrupted version of a previous, internally-consistent charm, but also as evidence of an unusual and somewhat paradoxical phenomenon, namely that charms in the English cultural tradition sometimes show a greater continuity over the years than from place to place in the same period of time. Take this mid-nineteenth century charm to help heal a scalding, recorded near Tavistock in Devon and cited in Thomas (1971: 212): 
Two angels came from the West.

The one brought fire, the other brought frost.

Out fire! In frost!

In the name of the Father, Son and Holy Ghost.

Which of the two following charms is more like it, one recorded at a similar time in Sussex and cited in Latham (1878: 35):

There came two Angels from the North;

One was Fire, one was Frost.

Out, Fire; in Frost,

In the name of Father, Son and Holy Ghost.

or the one recorded by Pepys, two hundred years earlier? Though both nineteenth-century versions have two angels, as against the other example's three, there is a feature which the Tavistock and the Pepys examples share: that the angels brought fire and frost (instead of one "being" fire, while the other "was frost"). Contrariwise, a case can be made that the Sussex charm is closer to Pepys' example than the Devonian, in that they both begin "There came" (not "Two angels came") and that they both omit the definite article before "Father" in the final line, in contradistinction to the Tavistock example. Either of the nineteenth-century examples could be said to be closer to the seventeenth-century one than to one another, and indeed not one of the three charms has the angels coming from the same point of the compass; the point of this excursus is that the "same" charm can be said to vary less over time, than from place to place.

Other sections which appear restrictedly in certain charms include the names-section and the origins-section. A names-section is a list of (often magical or holy) names, sometimes systematically conflated with other data as in the Second Merseburg charm. If we look at lines 3-5a, which in translation run:

then Sinthgunt sang over it,

then Frija sang over it, then Woden sang over it and Sunna his sister, and Volla her sister,

we can see these lines form a names-section. But seen as part of the charms as a whole these lines can be identified as a names- 
section which is at the same time a part of the historiola, and the lead-in to the magic formulæ. The names of benevolent and powerful mythological figures, filling the same metrical slots, here support the positive goal of healing. The function of a names-section may equally be to achieve the more negative goal of expelling or exorcising disease-spirits by naming their secret names and thus having power over them (and this naming is often done by the protagonist of the historiola). This negative use of a names-section is reminiscent of the role of an origins-section. This is a chiefly FinnoUgric feature, although embryonic origins-sections are sometimes found in Germanic charms. ${ }^{45}$ A good example of it appears in this segment of a variant of a common Baltic-Finnic charm against snakebite (this particular one was recorded from Leenu Saar in Ambla, Estonia in 1892):

Madu musta, moa-alune, halli aedade alune, kiheva kivi alune, läbi vetede pugeja!
Black snake underground, under fences, grey-one, under stone, hissing-one, through waters, crawling-one! ${ }^{46}$

Here the enumeration of the characteristically low haunts of the snake has the function of instructing the snake in its non-importance, of "finding it out", or as Honko (1993) has it "to remind the affliction and the agent who caused it [---] that the source of the affliction does not have the power to depart from its allotted place in the universe." This perhaps helps the patient feel rather superior, to move them from shock to outrage. It also serves the function of mythical diagnostication. ${ }^{47}$ Sometimes a complete aetiological legend (a combination of origins-section and historiola) is told. If the cause of the wound or illness etc. has been found out, and invoked, it can be dealt with subsequently; indeed, some folklorists (e.g. Conrad 1989) see healing charms as typically having a bipartite basic structure: first, statement of problem, then, remedy. ${ }^{48}$ The problem (e.g. the disease or disease agent) is stated in such a way as to suggest it has a magical character, for only then can a magical remedy be appropriate, or effective. Thus, the names of a names section are usually magic names, and the places mentioned in an origins sections are usually mythical locations.

The similarity of Finno-Ugric origins-sections to the typically IndoEuropean names-section is highlighted well by an oral testimony, 
record of which is now held in the Central Estonian Folklore Archives at the Literary Museum of the Estonian Academy of Sciences, which states that after the beginning of the process of snakeadjuration, siis hakkab ussi nimesid nimetama 'next, the snake's names were named' (Roper forthcoming). Sometimes the names and origins are enumerated alternately as in the example above, and sometimes as in the Vepsian example below (collected from Irina Eliseeva in Shoksh, Russian Karelia in 1942) they follow closely on one another:

$\begin{array}{ll}\text { Tii, tii, tihikiine, } & \text { Snn, snn, snakekins, } \\ \text { vouged tihikiine, } & \text { White snakekins, } \\ \text { must tihikiine, } & \text { Black snakekins, } \\ \text { kird'av tihikiine. } & \text { Many-coloured snakekins! } \\ \text { Mina sinu kodin tedan: } & \text { I know where you live: } \\ \text { aidan ruzus [---] } & \text { under the fence [---] }\end{array}$

The use of the diminutive in the first four lines and of the familiar form of "you" in line 5 are indicators of contempt, or at least condescension. Here the brief origins-section (or perhaps one should rather say origins-clause in this case) is introduced by the remarkably threatening "I know where you live." Indeed one could say that in this case it is the names-section and the invocation which have been conflated. The invocations of non-narrative charms often feature or lead into extended naming, or extensive origins-sections, as a means of achieving power over what they are forced, in the absence of a mediating historiola, to address directly. Conversely, invocations of particularly dangerous diseases or disease spirits may involve a minimal use of naming: Kent (1983) gives the example of a Czech erysipelas charm in which "the exorcist could have used the informal Ty, Nadcho! 'You, Rose!' to call forth the disease, [instead of the formal Nadcho!] [---] but this would have given too much explicit referential weight or power to the illness." This can be seen as a different tactical pursuit of the same strategic goal; neither brief reference, nor expanded pejorative naming show the illness too much respect.

One method of analysing the workings of the rhetoric of a charm is to use, following Kent (op. cit.), a form of notation originating in linguistics to illustrate the conversions of semantic features rhetorically achieved by the charm's string of words. To apply this to a 
brief apotropaic example, collected in "the Eastern Counties" and to be used "sewn up in the dress, etc." as a precaution against evildoers (Northall 1892: 140):

Whoever thou art thou meanest me ill

Stand thou still

As the river Jordan did

When our Lord and Saviour, Jesus,

Was baptized therein,

In the name of the Father, etc.

The situation at the beginning and its subsquent conversion can be characterized as:

[-known], [-benevolence], [-safety] $\rightarrow[+$ known], [+benevolence], [+safety]

[+mobility] $\rightarrow[-$ mobility $]$

[+human] $\rightarrow[+$ divine $]$

What might be called the drift of the charm is from worldly to biblical and otherworldly. To formulate the conversions in a charm will be most useful for those charms in which there is a move from statement of problem to remedy, such as in the one above, but describing the drift is justifiable in the case of a much larger number of charms, and will often be seen to be to, or from, markedness, specificity and foreground (and their reverse poles: unmarkedness, generalness and background).

As to the classification of charms, it seems that there are three possible methods. Firstly, they may be classified by the type of magical influence (sympathetic magic, antipathetic magic, transferential magic, magic involving amulets, magic involving herbs, verbal magic, written magic, etc.): Grendon (1909) orders his work with a division of this sort. Many charms, however, can fall into two or three of the above categories, which tends to restrict the categories' usefulness beyond a certain point. Secondly, it is possible to classify charms according to their area of application or subject; such subdivisions could be Agricultural charms, Apotropaic (or Protective) charms, Household and Occupational charms, Healing charms (or "Livelihood charms"), and Curses (this latter group is for all so-called "negative charms", which in practice are often in- 
verted versions of beneficial prayers and charms). These categories could be broken down into subdivisions - healing charms would consist of the subset of sprain-charms, St. Antony's Fire charms, ${ }^{49}$ bloodstaunching charms, and so on. This form of division also has its uses, but again in practice charms can be used for other diseases than those the folklorist has tidily put them down for, i.e. they are often multifunctional, and can change their application, just as the Chadwicks (1932) note occurring in Polynesia, where what were originally genealogical songs came to be used as charms (and as lullabies).

The third method of classifying charms is by their formal features. For example, there is a widespread type of charm (there are German, Anglo-Saxon, Serbian and other examples) which involves counting down (usually from nine) to zero in a formulaic series, in order to bring about the disappearance of something, usually a disease. If these charms were only classified according to their subject, i.e. what disease they were there to cure or palliate, then they would not be grouped together, hindering efforts at tracing their temporal-geographical distribution and the putative genetic links between them. Other, more strictly similar charm-types exist and have existed throughout Europe, for which there are good historical reasons. According to Bozóky (1992), approximately by the beginning of the eleventh century, after an initial period in which charms had been obtained from pagans, written down and suitably adapted $^{50}$ as northern Europe was gradually Christianized, Christian monks and priests began to compose new charms not derived from pagan models. To account for the similarity in form of charms through much of Europe (i.e. for the existence of pan-European charm-types) she suggests that these charms must have originally been written in Latin, sent or taken from one monastery to another, and sooner or later translated into the local languages. Assuming she is correct as to their original language of composition ${ }^{\mathbf{5 1}}$ (or at the least the language of their subsequent transmission was Latin), it seems good practice to follow Bozóky (and to be in opposition to Ebermann (1903) where, in fact, a much larger number of examples is presented) and use Latin names for them: Super petram (against toothache), Longinus, Tres virgines, In sanguine Adæ, Sanguis mane in te, Flum Jordan (all to staunch bleeding), Job sedet in sterquilinio (against "worms"), ${ }^{52}$ Tres boni fratres, ${ }^{53}$ Tres angeli, 
Christus te sequitur, Ante fuit Christus quam lupus, ${ }^{54}$ Jesus stetit crucifixus, Jesus natus est in Bethelehem, etc.

An example of an originally Latin charm-type which is vernacularized is evident in our own tradition, where we find in an eleventh-century manuscript a variant of Super petram headed Contra dolorem dentis and beginning "Christus super marmoreum sedebat", another comtemporaneous manuscript has a charm headed Wið toðece 'Against toothache', which runs "Sanctus Petrus super marmoreum" ${ }^{55}$ whereas the nineteenth century ecotypes ${ }^{56}$ of it quoted above are in English local dialects. Bozóky goes on to suggest that lay influence asserted itself in the fourteenth and fifteenth centuries, with the rise of literacy, and that charms (or at least charmsections or various formulæ) were composed once more in vernacular tongues and in vernacular poetic forms and metres. In the absence of any history of the genre of verbal charms in England (or in the Greater Europe), Bozóky's description seems plausible.

Smallwood (1989: 218), however, suggests that the issue of the circulation of charms in medieval Europe needs further investigation:

We know too little about the migration and lending of medieval codices to suggest how often the charms might have travelled in more formal written texts from country to country [---] besides what could be carried in the memory.

He expands on Ebermann's and Bozóky's almost exclusive emphasis on the role that monks and monasteries are supposed to have played in the transmission of charms by putting forward other classes of people similarly mobile who may well have played their own significant roles in the process: students ("especially medical students"), seamen, soldiers and pilgrims. He arrives at the conclusion that "the whole question of how medieval charms circulated across national or linguistic frontiers still awaits adequate discussion."

\section{TOWARDS A PROXEMICS OF VERBAL CHARMS}

A charm is never "performed" as quickly and informally as, say, a proverb can be. A video recording (FAV 91) in the archives of the Estonian Museum of Literature makes that clear enough. This video 
shows the full procedure one old Estonian woman, Minna Kahusk from the village of Mikhailovka in the Omsk region of Russia, follows when attempting to heal the "rose" disease (St. Anthony's Fire) using a verbal charm. Firstly, the charm is spoken over some wool, then the Lord's Prayer is recited, then three crosses are made with a knife over the wool, the charm is then spoken in a normal tone of voice right down on to the wool, as if she was blowing on it. Three more cross-shapes are made with a knife, and the charm is then spoken over the wool once more. This time the wool is held in the cupped hands of the charmer right up to her mouth, and a formulaic phrase Mina olen arst, Jumal annab abi 'I am a healer, God give help!' follows this recitation of the charm. The charmer then makes three more cross-shapes with the knife, speaks the charm for a third time, makes three more cross-shapes with the knife, recites the Lord's Prayer once again, makes three final cross-motions with the knife, and then wraps the wool in newspaper ready to put in on to the diseased part of the patient. This video-recording of a woman performing a healing charm from a relict area for Estonian folklore deep inside Russia makes it very apparent just how much we can miss when we only have bare texts, and it also confirms the need for terminology to record such behaviour and the special rules or conditions governing such procedures.

One limiting condition is that only certain people can legitimately perform certain verbal charms. ${ }^{57}$ Anna Kuusik, for instance, had a repertoire of over one hundred charms and charm-variants in the Estonian language. She could not however legitimately perform all of them: as a midwife it was taboo for her to perform blood-staunching charms (Kõiva 1990: 169). And only certain contexts legitimize them; this is what Foley (1995: 47-49) refers to as a performance arena, any time and place in which a charm's words can possibly achieve "their special power". Such a specific time may be for example at dawn, or at a particular time in the moon's cycle, a particular day of the week, ${ }^{58}$ or a particular day in the folk-calendar. For example, charms to frighten off sparrows from the fields had to be spoken on New Year's Eve in the Estonian counties of Tartu and Võru. Similarly, Estonian charms against wolves were meant to be spoken in the period from Passion Week until the first cattle were born (Kõiva 1990: 176-167). It is just this kind of performance detail, what we might call the proxemic ${ }^{59}$ aspect of verbal charms, 
that is the most difficult aspect to describe. This is not so much due to lack of terminology, as to a general tendency among both compilers of books of magic and the early folklorists often not to record such details. Many texts in the Anglo-Saxon magico-medical Leechbook and Lacnunga are exceptional in this respect as they include performance instructions together with explicit or implied utterance instructions. For example, in Text 8 of Cockayne (18641866, Vol. 3), the verbs used make it clear that the gibberish is to be sung or ongalan 'chanted', and the sensical part is to be cwepan 'spoken' (Vaughan-Sterling 1983: 193-194). These Old English texts also state precisely what ingredients (e.g. which herbs) are needed, and, though to a much lesser extent what accessories are needed for a charm to work. If these are not mentioned they can be very tricky to reconstruct retrospectively and speculatively with any accuracy. Although one can easily realize that each time a symbol is found on the page the charmer has to make the sign of the cross at that stage of the charm (just as N.N., or sometimes simply N., in magic formularies stands for a name ${ }^{60}$ - usually that of the sick person, but sometimes that of the healer - to be inserted by the charmer), other gestures and customary actions are harder to trace. As Kõiva (1990: 168) reminds us, we tend to forget that the disappearance of a charm often implies the disappearance of a particular corresponding custom too. How could one, for example, imagine from the bare charm texts in Tedre's anthology of folk verse (19691974) that the healing process of which these charms can be a part when used by the tradition-dependent folk-healer Laine Roht also involves the use of a Zwischenträger. A Zwischenträger (literally, an 'intermediate element') can be a cloth, a rag, a piece of linen etc. used to wipe away illness.

It is then buried under the eaves, near the well, in the manure pile or some other place, to hasten the decay of the agent into whose very fibre the diseased part has been magically transferred. (Hand 1985: 248)

Similarly, from the bare text of a particular Russian charm containing the image of a key in the ocean, one would not know that at the same stage in the charm the image finds expression in the customary action of actually dropping a key into some water (Petrov 1981). 
For these reasons, attempts to describe charms as performed should be bipartite, concentrating on the charm's utterance (addressing such questions as: is it muttered? is it yelled? is it chanted in a singsong? must it be delivered in a context of complete silence? what tempo is it delivered at? is the pronunciation marked or unusual? is there any use of mimicry? is it spoken over a certain object or foodstuff? are the breaks between the sections of the charm marked by pause or changes in vocal tone? if the charm is repeated a set number of times, are there pauses between these repetitions or does the utterance proceed without time for breathing spaces?) and the charm's enactment (the definite actions, gestures, facial expressions, noises, physical contact, "audience" participation, offerings, use of ingredients and accessories, which surround and accompany the words of the charm and the recital of prayers, especially the Paternoster before or after to strengthen the charm). ${ }^{61}$ Putting these together, we can then describe the charm performance. Such an analysis can, if feasible and successible, enlarge our understanding: we can, for example, thus realize that the Old English charms Wið færstice and The Nine Herbs Charm, as Weston (1985: 185) points out, do not conclude with their last formulaic phrases, but rather both culminate in a final wordless gesture blowing the poison from the patient and plunging a knife into a herbal potion, respectively.

Verbal magic, as hinted at above, is usually far from automatic, its success is conditional. For a charm to be performed, various customary preconditions may also first need fulfilling, such as gathering ingredients at a specified time from a specified place, divination, prognostication, purification of the patient (and their surroundings) e.g. by censing, or other preparations. A charm against wolves may require the prior observation of wolf-tracks. Some Estonian charms even first required a favourable wind-direction for them to work (Kõiva 1990: 179). Equally, though less typically, there may be customary postconditions for the charm to be effective, such as continued use of Zwischenträger night and morning by the patient. One might note that such elaborate sets of conditions would be useful to a charmer wishing to explain away failure by claiming that the external circumstances had not been propitious or that the conditions had not been followed to the letter. 
Healing charms may be accompanied by particularly elaborate rituals involving massaging or stroking, blowing upon or spitting on the sick part of the patient, the application of special preparations etc. Indeed, as part of a total healing ritual, the speaking of words may only play a short, though significant part. Writing about the Estonian charm-tradition, Mare Kõiva (1995: 227), has remarked on the variability of verbal forms as compared with "the rites and healing methods associated with them":

The action accompanying an incantation (demarcation of the diseased area, crossing the sick spot or the remedy, symbolic rites of washing, anointing, burning etc. the disease, offering the "curing water of salt" to an old sacrificing stone or site, crossroads or some critical place) have survived without changing much within the past few centuries.

It may very well be true for other charm-traditions as well that these proxemic features (and the superstitions or folk-explanations accompanying them) are more enduring than forms of words. However, it is precisely about these proxemic features that we tend to have the least information ${ }^{62}$ and also the smallest number of descriptive terms. Even if such a comprehensive description of the proxemics of a particular verbal charm will frequently prove to be impossible, we at least have the necessary terminology for whenever the material is available, and to serve as a reminder that, in the words of Robert Georges (cited Foley 1995: xiii), the textual artefact "is a record of, and not the same thing as, the behaviour complex it represents."

\section{Comments}

${ }^{1}$ Compare the Chadwicks' (1932: 839) observation: "all the spells known to us from ancient literatures seem to have been in poetry."

${ }^{2}$ In addition to the terminologies of Poetics, Rhetoric and Proxemics which, in Europe at least, tend to be applicable relatively cross-culturally, we could devise terms for a Formulaics and a Thematics of certain charmtraditions, and indeed for individuated international charm-types. The Formulaics would be concerned with the words, the "ready-made surface structure[s]" (Kiparsky 1976) and their formulaic connections in a given 
tradition, while the Thematics would address itself to the ideas, the 'deep structures' those words express.

${ }^{3}$ Grendon (1909), Dobbie (1932), Storms (1948) and Grattan and Singer (1952).

4 This is the case generally in a wide variety of European (and other) cultures; for example, over three quarters of the 372 charms collected in the second half of the nineteenth century by the energetic Russian folklorist Maikov were for use against disease (Petrov 1981).

5 The definitions of the verb 'to charm' in the Dictionary of Newfoundland English, “to cure an ailment by paramedical means" (DNE 'charm' v.1), and in the English Dialect Dictionary, "to cure some disease by a supposed supernatural cure; to bewitch" (EDD 'charm' 3.v.), both suggest that the most common form of charm (or the most significant kind in people's minds) were healing charms. See note 4 above. However, the wealth of definitions of the verb in the Oxford English Dictionary show it to historically have had a wider semantic field for the word, even when we exclude the later figurative senses of the verb, for example: "to act upon with or as with a charm or magic, so as to influence, control, subdue, bind, etc.; to put a spell upon; to bewitch, enchant", "to endow with supernatural powers or virtues by means of charms; esp. to fortify against evil or dangers", "to mark with a symbol as a charm, (obs.)", "to work charms, use enchantments or spells, practise magic", "to conjure, entreat (a person) in some potent name, (obs.)"; examples of phrasal use of the verb are also given, e.g.: to charm to, to charm from, to charm asleep, to charm away, to charm out, etc. (OED 'charm' v. 1, $2,2 b, 3,6,1 b, 1 \mathrm{c})$. These definitions give us a broader picture of what the purpose and effects of charms have been held to be in addition to curing. Incidentally, the earliest citation in English the OED gives is dated at c 1300 .

${ }^{6}$ Grattan and Singer (1952: 38). Compare Clark Hall's (1960: 147) definition: "galdor(ea) n. sound, song, incantation, spell, enchantment". The rootword (and the practice it describes) must have originated in (or before) the period of Common Germanic language and culture as reflexes of the root in other ancient Germanic languages demonstrate. For instance, in the Old High German Second Merseburg Charm biguolen, (literally meaning "sang over", i.e. "enchanted") is the direct cognate of the Old English verb begalan ('to charm', 'to sing with magical effect'); the Old Norse cognate is similarly magical, Zoëga (1910, p.158) notes that the notion "to charm" was expressed as gala galdra 'to sing magic songs'. Interestingly, the root of this word survives in OE nihtegala, ModE nightingale (literally, 'night-singer'). 
The latest OED citation for the verbal form dates from c 1205 Heo bigolen Pat child mid galdere swiðe stronge 'She charmed the child with very strong charms' in Lay. 19257. This prompts the thought that guile (a word for which the OED claims "no certain etymon is known") also derives from the same root, and that 'to beguile' could represent the same verb as OE begalan and early ME bigale (both of the latter meaning 'to charm with incantations, etc.; to enchant', OED 'bigale', v.) after a downward semantic shift: the earliest OED citation of beguile (in the form bigiled dates from 1225, about twenty years after the last recorded use of the verb bigale. Such a downward shift in meaning from 'to perform magic' to 'to trick' could help explain (or may be a side-effect of) the adoption of the high status Frenchderived 'charm' by users of traditional magic and their clients in the thirteenth century (the first written citation of 'charm' the OED gives, being, as noted above, from c 1300). It would have been far from being the only native word in this period undergoing downward semantic shift and facing partial or total invasion of its semantic field by a French-derived word.

7 This root survives nowadays in the verb 'to foretell', and in the local English and Scots phrasal verb 'to tell out', the latter being defined by the New Shorter Oxford English Dictionary as 'to drive away (pains etc.) by uttering incantations.'

${ }^{8}$ Bosley (in Lönnrot 1989: xxxix) seems to recognize this too: when speaking of the verbal charms featured in the Kalevala, he remarks "the incantations [-in] the epic are like coloratura arias".

${ }^{9}$ Greene (1993: 502) makes the more extreme claim that "the language of the charm privileges sound over meaning."

${ }^{10}$ Creed, in Lord (1986: 137) usefully defines sound-patterning as "the sharing of sound by syllables usually separated from each other by other syllables", i.e. always as involving some form of repetition.

${ }^{11}$ Laine Roht, the South Estonian folk-healer speaks of the need for the patient to believe in the cure for it to have any effect.

12 Because words in addition to possessing a dictionary denotatum, also carry some connotata too, they (especially nouns) can give off an indefinite ur-poetic radiation in the right contextual atmosphere. Similarly, even sound strings may, perhaps by triggering popular etymologizing or fancy, have the same effect.

${ }^{13}$ In the fifteenth-century, Pico della Mirandola while discussing Cabalistic texts remarked that "a word devoid of all sensible meaning has most influence over demons" (Izutsu 1956: 130). 
${ }^{14}$ Stanford (1967: 81), discussing the relative merits of sound versus sense in Ancient Greek magic, comments "the papyri have preserved many magical spells in which the sound seems to matter most."

${ }^{15}$ One such example appears in a Middle High German text intended to "bless a house against the devil":
uuola uuiht taz tu uueist
tuz tu uuiht heizest, taz tu niuueist noch nechanst cheden chnospinci.

Murdoch (1983: 54) renders this "It is good, o devil, that you know you are a devil, and do not know and do not know, nor can say chnospinci."

${ }^{16}$ One particular magical text written on a papyrus in the Eighth book of Moses from Græco-Roman Egypt takes this to extremes by invoking its addressee successively in "birdglyphic", hieroglyphic, Hebrew, Egyptian, "baboonic", "falconic" and Hieratic. It is accompanied with the instruction to then "clap three times, go "pop, pop, pop" for a long time; [and then] hiss at some length", (Betz 1986).

${ }^{17}$ Gaster (1928) noted that the Canonical Exorcisms of the Catholic Church contained "a list of holy names by virtue of which the demon is forced to obey the injunctions of the exorcist" - generically speaking, at least, a form of verbal charm.

${ }^{18}$ Grendon (1909: 194-197), although Storms (1948: 308) shows this eleventh-century English charm against dyssentry in a continuous format with neither metrical nor phrasal lineation, which suggests he sees it not as a jingle charm, but as a gibberish charm.

${ }^{19}$ A reflex of the common Uralic root of this word loitsima is now extinct in Estonian, but had meant 'to pray' (Loorits 1949: 228). This serves as another reminder of the connection between spells and religiously-sanctioned verbal acts. Indeed, the exorcisms and benedictions the modern Christian minister still pronounces have some analogies with the subjects of the present study, not the least of which being that these verbal forms are intended to "mediate" supernatural forces.

${ }^{20}$ Rodrigues (1993: 20) in discussing the Anglo-Saxon charm, suggests that "their irregular metres indicat[e] [ - ] oral traditions older than those of classical Anglo-Saxon poetry." While Foley (1980) thinks that the "irregularities which mark the metrical structure of Old English charms suggests a common attention to patterns of sound other than those customarily associated with "normal" poetry." 
${ }^{21}$ Lord (1995: 11), speaking from long experience, notes that "formulas do not exist to make memorization easier, but rather they make memorization unnecessary."

${ }^{22}$ For example, an epithet traditionally associated with a particular noun may appear at times before the noun, and at other times a little after the noun.

${ }^{23}$ Jakobson famously, if rather obscurely, remarked that the hallmark of verse is that in it "equivalence is promoted to the constitutive device of the sequence", which can for our purposes be taken to mean "phonetic, rhythmic, syntactic and other kinds of equivalence are the principle(s) on which poetic sequences (and especially formulæ) are constituted."

${ }^{24}$ An important principle on which Watkins (1995: 679) bases his comparative Indo-European poetics on is his belief that ring composition "is not terribly common outside of the archaic Indo-European speaking world."

${ }^{25}$ For examples see Hieatt 1987.

${ }^{26}$ This is, as Watkins (1995: 9) points out, the same order as the Homeric Greek formula keimelia te probasin te, whose constituents express the same idea (or "theme") - movable wealth and immovable wealth.

27 Parry and Lord had insisted on an archetypal model for all oral traditions based on the convergence between Homeric epic and a single subgenre of South Slavic oral poetry [---] It is as if we insisted on the Shakespearean sonnet alone as the one true model for all literature, narrative or lyric, prose or poetry. (Foley 1996: 26)

${ }^{28}$ Conrad (1983) provides a South Slavic formulaic introduction Sjedi urok na pragu, urocica pod progum 'The spell sits on the threshold, his mate is under the threshold'.

${ }^{29}$ Compare Lord (1960: 101) "Each performance is "an" original,[-] not "the" original", and Sharp (1907: 15) "at every moment in its history it exists not in one form but in many."

${ }^{30}$ I discuss this question with reference to a concrete example of a witch and her pupil in a paper in the forthcoming Proceedings of the Media, Folklore and Mythology Conference organised by the Department of Folk Religion and Narrative Research of the Institute of Estonian Language and the Baltic Institute of Folklore and held in Tartu, Estonia, November 1997.

${ }^{31}$ These terms are versions of those in Vlasova (1972). 
${ }^{32}$ Sebeok (1966: 385), discussing the charm-tradition of the Cheremis (a Finno-Ugric people found in Russia along the Middle Volga, and who are also known as the Mari), states "the effectiveness of a charm depends upon its literally exact citation [---] any departure from its precisely set mechanism may render the whole magic ineffective."

${ }^{33}$ Olsan (1989: 444) shows how an Anglo-Saxon example of a fairly common European charm had "canabit" for 'natabit' by auditory substitution.

${ }^{34}$ In this connection, we can note the significance of Larrington's (1996: xxviii) description of the Old Norse metre Galdralag (literally, 'spell-measure', the measure in which to compose verbal charms) as a "repetitive metre." Would it be to great a leap of the imagination to see that a popular view of the repetitiveness of charms could be behind one sense of the dialect verb cham /čam/ and/ča:m/: 'to say the same thing over and over again' (EDD 'cham', v.2.)?

${ }^{35}$ Or as Petrov (1981) has it 'personageless charms', a description which emphasizes the lack of protagonists.

${ }^{36}$ Thomas (1971: 272) rather impressionistically characterizes narrative charms in early modern England as being "barely intelligible bits of semireligious verse describing supposed episodes in the life of Christ or the saints.”

${ }^{37}$ When discussing the Estonian equivalents of this kind of charm, Oinas (1985) uses the rather literal rendering 'tell charms' (from the Estonian jutustavad loitsud). The use of the term 'narrative charms' establishes the existence of pan-European comparanda, but 'tell charms' is a felicitious term too, as it neatly encompasses the micro-story that is being told, as well as the frequent telling of the magic formulæ by that story's protagonist.

${ }^{38}$ At root, both 'to conjure' and 'to adjure' mean 'to command'.

${ }^{39}$ Indeed some charms are recorded as ending "Amen", or "Amen. Amen. Amen", which is in Christendom the most widely recognized word of commendation, of asking/hoping/pleading that "it be so". Furthermore, charms may be followed by prayers (especially the Lord's Prayer), which can be seen as being an extended form of ratification as well as a hedging of supernatural bets.

${ }^{40}$ Both collected on the 3rd of August, 1995. For texts see Roper "Two Recently-Recorded Estonian Snake-Charms" in Lore and Language (forthcoming). 
${ }^{41}$ From the RKM collection in the Estonian Folklore Archives, text RKM II 92, 223, collected in Kambja in the Seto region in 1958.

${ }^{42}$ Wiedemann's text 394 (14).

${ }^{43}$ From Jakob Hurt's collection in the Estonian Folklore Archives, text H II 62,685 (46), also collected in the Seto region: this time in the vicinity of Vastseliina.

${ }^{44}$ Bynum (in Stolz \& Shannon 1976) warns that "the rationale for families of formula" (which would be the province of the Formulaics of a given tradition) "is detectable only when one knows a great deal about a particular culture."

${ }^{45}$ A twelfth-century German charm against lameness in horses, cited in Braekman (1983: 476) contains the line: muutwas . markwas . war come du do. 'Muutwas, Markwas, from whence did you arrive there?', the latter half of which seems like an origins-section manqué. The next line of the charm which in function is expulsory still however makes reference to origins: var in dine ciprigre . in dine marisee 'Go away to your mountains, to your lakes!'

${ }^{46}$ M. J. Eisen's collection in the Estonian Folklore Archives, text E 1148 (1892).

47 The cause [of disease as identified in Baltic-Finnic charms] can be an animal, or a mythic being, or also locations (cf. Finnish 'tarttumasija' place of contagion, 'puutuutasija' place of interference), or even, for instance, iron. (Ilomäki 1992)

Bailey, speaking of the extended, over two-hundred line origins-section in runo 9 of the Kalevala, declares that reciting "the origin or 'birth' (synty) of the offending substance to demonstrate one's power over it [---] is sound psychotherapy, as we have since discovered" (Lönnrot 1989: xxxvii).

${ }^{48}$ Likewise, Weston (1985) sees charms as possessing a basic structure of a) gathering or evoking of power, and b) chanelling and discharging that power. This is in turn reminiscent of Greene's (1993) analysis of invocations, both in poetry and in charms, into a first part of naming someone or something absent, and a second part of summoning them to appear and/or do something. This is itself reminiscent of our contemporary health service with its bipartite mode of operation: first diagnosis, then referral for treatment.

${ }^{49}$ That is charms for the healing of gangrenous ergotism. Park (1992: 75) remarks on the connections between particular saints and particular diseases in Western medieval Christianity, especially after about 1300, when 
"a dramatic shift occurred in the cult of saints [--- viz.] an increasing number of [healing] miracles began to happen without direct contact with relics, mediated instead by an image of the saint in question or by a vision or prayer." She goes on to give examples of the association of St. Lazarus with leprosy, "St. Sebastian with plague, [---] St. Mathurin with mental illness, St. John with epilepsy, and St. Maur with gout."

${ }^{50}$ From $500 \mathrm{AD}$ onwards West European charms featured Christ as a healer (Hoffmann-Krayer \& Bächtold-Staubli 1927/1942: 1225).

${ }^{51}$ See also Ebermann (1903: 135): "Der Segen wird oft in lateinischer sprache verfaßt" [The charms were often composed in Latin].

${ }^{52}$ Some German variants of this charm contain the extraordinary rhymepair: "Mist" and "Christ".

${ }^{53}$ This is a case in point as an example in twelfth-century German predates the first recorded Latin example by a century.

${ }^{54}$ This charm-type appeared in Middle English as per nes i-nemned ne wolf ne pef.

${ }^{55}$ Storms (1948: 287-289) notes that "apparently the formula was so wellknown that it was not considered necessary to give the rest".

${ }^{56}$ An ecotype (also "oikotype") is a special version of a charm (or of any other example of a folkloristic genre) limited to a particular cultural area in which it has developed differently from examples of the same charmtype in other areas, because of national, political, geographical and historical conditions. Von Sydow (1948) originally used this term only to refer to the variants of folktales.

${ }^{57}$ Compare Honko's (1993: 49) formulation "Oral poetry needs a stage."

${ }^{58}$ According to Kõiva (1990: 178) Germans and Latvians both considered Fridays as the most suitable days for charming upon.

${ }^{59}$ In the present study the word 'proxemic' will be taken in the sense of the linguistic and metalinguistic performance aspects of an oral genre. See Crystal (1997) for a somewhat different definition suited to linguists.

${ }^{60}$ The same is true of liturgical texts, such as the Book of Common Prayer.

${ }^{61}$ Similarly, in Estonian, the Paternoster was used in the healing processes for almost all of the total number of diseases (according to folk tradition there were 144). 
${ }^{62}$ Judiciously used, perhaps folk tales which feature witches could be used as a form of "corroborative evidence" to fill out our knowledge of such details.

\section{References}

Bartashevich, G. 1993. Zagovory [Charms]. Vostochno-slavianski folklor: slovar nauchnoi i narodnoi terminologii [East Slavic Folklore: a Dictionary of Scientific and Folk Terminology]. K. Kabashnikov, et al. (eds.) Minsk: Nauka i tekhnika.

Betz, H. D. (ed.) 1986. The Greek Magical Papyri in Translation (including the Demotic Spells). London: University of Chicago Press.

Bloomfield, M. 1964. The Form of Deor. Publications of the Modern Language Association of America 79, pp. 534-541.

Bozóky, E. 1992. Mythic Mediation in Healing Incantations. Health, Disease and Healing in Medieval Culture. S. Campbell, B. Hall, \& P. Klausner (eds.). London: Macmillan.

Braekmann, W. 1980. Notes on Old English Charms. Neophilologus 64 (Oct), pp. 461-469.

Braekmann, W. 1983. Notes on Old English Charms II. Neophilologus 67 (Oct), pp. 605-610.

Brown, T. 1970. Charming in Devon. Folklore 81, pp. 37-47.

Bynum, D. 1987. Of Sticks and Stones and Hapax Legomena Rhemata. Comparative Research on Oral Traditions. J. Foley (ed.). Columbus, Ohio: Slavica.

Chadwick, H. M. \& Chadwick, N. K. 1932. The Growth of Literature IIII. Cambridge: Cambridge University Press.

Clark Hall, J. R. 1960. A Concise Anglo-Saxon Dictionary. 4th edition. Cambridge: Cambridge University Press.

Cockayne, O. 1864-1966. Leechdoms, Wortcunning and Starcraft in Early England. London: Longman.

Conrad, J. L. 1983. Magic Charms and Healing Rituals in Contemporary Yugoslavia. Southeastern Europe 10 (2), pp. 422-444.

Conrad, J. L. 1989. Russian Ritual Incantations: Tradition, Diversity and Continuity. Slavic and East European Journal 33 (3).

Crossing, W. 1911. Folk Rhymes of Devon. London: Chatto and Windus.

Crystal, D. 1997. A Dictionary of Linguistics and Phonetics. 4th edition. Oxford: Blackwell.

Davies, O. 1996. Healing Charms in use in England and Wales 17001950. Folklore 107, pp. 19-32.

Dobbie, E. (ed.) 1942. Anglo-Saxon Poetic Records volume VI: AngloSaxon Minor Poems. New York: Columbia University Press. 
Ebermann, O. 1903. Blut- und Wundsegen in ihrer Entwickelung dargestellt [Blood-staunching charms and wound-charms, described in the course of their development]. Berlin.

Foley, J. 1980. Epic and Charm in Old English and Serbo-Croatian Oral Tradition. Comparative Criticism: a Yearbook 2. Cambridge: Cambridge University Press, pp. 71-92.

Foley, J. 1987. Reading the Oral Traditional Text: Aesthetics of Creation and Response. Comparative Research on Oral Traditions. J. Foley (ed.). Columbus, Ohio: Slavica.

Foley, J. 1995. The Singer of Tales in Performance. Bloomington: Indiana University Press.

Foley, J. 1996. Signs, Texts and Oral Tradition. Journal of Folklore Research 33 (1), pp. 21-29.

Fry, D. K. 1981. The Memory of Cædmon. Oral Traditional Literature: A Festschrift for Albert Bates Lord. J. M. Foley (ed.). Columbus, Ohio: Slavica.

Gaster, M. 1925-1928. Two Thousand Years of a Charm against the Child-Stealing Witch. Studies and Texts in Folklore, Magic, Medieval Romance, Hebrew Apocrypha and Samaritian Archaeology II. London.

Grattan, J. H. G. \& Singer, C. 1952. Anglo-Saxon Magic and Medicine. London: Oxford University Press.

Greene, T. M. 1993. Poetry as Invocation. New Literary Review 24, pp. 495-517.

Grendon, F. 1909. The Anglo-Saxon Charms. The American Journal of Folklore XXII, pp. 105-237.

Grendon, F. 1930. Anglo-Saxon Charms. New York. (Reprinted: Norwood, Pa: Norwood Editions, 1976).

Grigson, G. (ed.) 1971. The Faber Book of Popular Verse. London: Faber and Faber.

Güttgemanns, E. 1977. Fundamentals of a Grammar of Oral Literature. Patterns in Oral Literature. H. Jason \& D. Segal (eds.). The Hague: Mouton.

Hand, W. 1980. Magical Medicine: The Folkloristic Component in the Folk Belief, Custom and Ritual of the Peoples of Europe and America. London: University of California Press.

Hand, W. 1985. Magical Medicine: An alternative to "Alternative Medicine". Western Folklore 44 (3), pp. 240-251.

Harland, J. \& Wilkinson, T. 1876. Lancashire Folklore. London: John Heywood.

Hieatt, C. B. 1987. On Envelope Patterns (Ancient and Relatively Modern) and Nonce Formulas. Comparative Research on Oral Traditions. J. Foley (ed.). Columbus, Ohio: Slavica.

Hoffmann-Krayer, E. \& Bächtold-Stäubli, H. (eds.) 1927-1942. Händwörterbuch des deutschen Aberglaubens [Dictionary of German Superstitions] I-X. Berlin: de Gruyter. 
Holloway, J. 1987. The Oxford Book of Local Verses. Oxford: Oxford University Press.

Honko, L. \& Timonen, S. \& Branch, M. \& Bosley, K. (eds.) 1993. The Great Bear: A Thematic Anthology of Oral Poetry in the Finno-Ugric Languages. Helsinki: Finnish Literature Society.

Hoppal, M. \& Pentikäinen, J. (eds.) 1992. Uralic Mythology and Folklore. Budapest \& Helsinki: Ethnologica Uralica I.

Ilomäki, H. 1992. Charms as Linguistic Expressions of Dichotomized Nature and Culture. Uralic Mythology and Folklore. M. Hoppal \& J. Pentikäinen (eds.). Budapest \& Helsinki: Ethnologica Uralica I.

Izutsu, T. 1956. Language and Magic - Studies in the Magical Function of Speech. Tokyo: Keio Institute of Philological Studies.

Jakobson, R. 1981. Selected Writings volume 3: Poetry of Grammar and Grammar of Poetry. The Hague: Mouton.

Kabashnikov, K. et al. (eds.) 1993. Vostochno-slavianski folklor: slovar nauchnoi i narodnoi terminologii [East Slavic Folklore: a Dictionary of Scientific and Folk Terminology]. Minsk: Nauka i tekhnika.

Kent, G. P. 1983. The Poetic Order of Healing in a Czech Incantation against Erisypelas. Southeastern Europe 10, No. 2.

Kieckhefer, R. 1989. Magic in the Middle Ages. Cambridge: Cambridge University Press.

Kiparski, P. 1976. Oral Poetry: Some Linguistic and Typological Considerations. 73-106 Oral Literature and the Formula. B. Stolz \& R. Shannon (eds.). Ann Arbor: CCAMS.

Kõiva, M. 1990. Estonskie zagovory-klassifikatsia i genrovye osobennosti. [Estonian charms - classification and generic characteristics]. Tallinn: unpublished dissertation.

Kõiva, M. 1995. From Incantations to Rites. Folk Belief Today. Mare Kõiva \& Kai Vassiljeva (eds.). Tartu: Estonian Academy of Sciences.

Larrington, C. (trans.) 1996. The Poetic Edda . Oxford: Oxford University Press.

Latham, C. 1878. Some West Sussex Superstitions Lingering in 1868. Folk-Lore Record 1, pp. 1-67.

Lévi-Strauss, C. 1963. Structural Anthropology. London: Basic Books.

Loorits, O. 1949-1957. Grundzüge des estnischen Volksglaubens I-III. [The essential features of Estonian folk belief]. Lund: Kung Gustav Adolfs Akademien for Folklivsforskening.

Lönnrot, E. 1989. The Kalevala. Oxford: Oxford University Press.

Lönnrot, E. 1992. The Kanteletar. Oxford: Oxford University Press.

Lord, Albert Bates 1960. The Singer of Tales. London: Oxford University Press.

Lord, Albert Bates 1987. The Nature of Oral Poetry. Comparative Research on Oral Traditions. J. Foley (ed.). Columbus, Ohio: Slavica. 
Lord, Albert Bates 1995. The Singer Resumes the Tale. M. L. L. Lord (ed.). London: Cornell University Press.

Murdoch, B. O. 1983. Old High German Literature. Boston: Twayne.

Newall, V. 1974. Encyclopedia of Witchcraft and Magic. London: Hamlyn.

Northall, G. F. 1892. English Folk-Rhymes: A collection of traditional verses relating to places and persons, customs, superstitions etc. London: Kegan Paul and Co.

Oinas, F. 1985. Studies in Finnic Folklore, homage to the Kalevala. Helsinki: Finnish Literature Society 387.

Olsan, L. 1989. The Arcus Charms and Christian Magic. Neophilologus 73, pp. $438-447$.

Ong, W. J. 1982. Orality and Literacy: the Technologizing of the Word. London: Metheun.

Park, K. 1992. Medicine and Society in Medieval Europe 500-1500. Medicine in Society: Historical Essays. A. Wear (ed.). Cambridge: Cambridge University Press.

Petrov, V. P. 1981. Zagovory [Charms]. Iz istorii russkoi sovetskoi folkloristiki [From the History of Russian Soviet Folkloristics]. A. A. Gorelov (ed.). Moskva: Nauka.

Porter, P. E. B. 1905. Around and About Saltash. Saltash: Dingle and Co.

Propp, V. 1958. The Morphology of the Folktale. London: University of Texas Press.

Rodrigues, L. 1993. Anglo-Saxon Verse Charms, Maxims and Heroic Legends. Pinner: Anglo-Saxon Books.

Roper, J. (forthcoming). Two recently-recorded Estonian Verbal-Charms. Lore and Language.

Rørbye, B. 1992. From folk medicine to medical folkloristics. Folklore Processed in Honour of Lauri Honko on his 60th Birthday. R. Kvideland (ed.). Helsinki: Suomalainen Kirjallisuuden Seura.

St. Leger-Gordon, R. E. 1982. The Witchcraft and Folklore of Devon. Gloucester: Alan Sutton.

Sebeok, T. 1966. Structure and Content of Cheremis Charms. Language in Society and Culture. D. Hymes (ed.). London: Harper and Row.

Sharp, C. 1907. English Folk Song: Some Conclusions. London: Methuen.

Singer, C. 1919-1920. Early English Magic and Medicine. Proceedings of the British Academy 9.

Stolz, B. \& Shannon, R. (eds.) 1976. Oral Literature and the Formula. Ann Arbor: CCAMS.

Storms, G. 1948. Anglo-Saxon Magic. The Hague: Martinus Nijhoff.

Story, G. \& Kirwin, W. \& Widdowson, J. (eds.) 1982. Dictionary of Newfoundland English. Toronto: University of Toronto Press.

Stuart, H. 1981. "Ic me on pisse gyrde beluce": the Structure and Meaning of the Old English Journey Charm. Medium Avium 50, pp. 259273. 
Stuart, H. 1981. Utterance Instructions in the Anglo-Saxon Charms. Parergon - the bulletin of the Australian and New Zealand Association for Medieval and Renaissance Studies. New series vol. 3, pp. 31-37.

Sunkuli, L. O. \& Miruka, S. O. 1990. A Dictionary of Oral Literature. Nairobi: Heinemann Kenya.

Tedre, Ü. (ed.) 1969-1970. Eesti rahvalaulude antoloogia I-IV. [An Anthology of Estonian Folk-songs]. Tallinn: Eesti Raamat.

Thomas, K. 1971. Religion and the Decline of Magic. Harmondsworth: Penguin.

Vaughan-Sterling, J. A. 1983. The Anglo-Saxon Metrical Charms: Poetry as Ritual. Journal of English and Germanic Philology 82 (2), pp. 186-200.

Vlasova, Z. 1972. K izucheniu poetiki ustnykh zagovorov. [Towards the Study of the Poetics of Oral Verbal Charms]. Russki fol'klor XIII: Russkaia narodnaia proza [Russian Folklore XIII: Russian Folk Prose]. C. N. Azbelev, et al (eds.). Leningrad.

Von Sydow, C. W. 1948. Selected Papers on Folklore. Copenhagen: Rosenkilde and Bagger.

Watkins, C. 1995. How to Kill a Dragon-Aspects of Indo-European Poetics. Oxford: Oxford University Press.

Weston. L. M. C. 1985. The Language of Magic in Two Old English Metrical Charms. Neuphilologische Mitteilungen 86 (6), pp. 176-186.

Widdowson, J. D. A. 1977. If You Don't Be Good: Verbal Social Control in Newfoundland. St. Johns, Newfoundland: Institute of Social and Economic Research, Memorial University.

Whitlock, R. 1977. The Folklore of Devon. London: Batsford.

Whitlock, R. 1992. Wiltshire Folklore and Legends. London: Robert Hale. Wright, J. 1898-1905. The English Dialect Dictionary. London: Henry Frowde.

Zoëga, G. T. 1910. A Concise Dictionary of Old Icelandic. Oxford: Oxford University Press. 